\title{
The Role of Philosophy in Modern Medicine
}

\author{
Mbih Jerome Tosam \\ Department of Philosophy, Higher Teacher Training College (HTTC) Bambili, University of Bamenda, \\ Bamenda, Cameroon \\ Email: mtosam2002@yahoo.com
}

Received December 28 ${ }^{\text {th }}$, 2013; revised January 28 ${ }^{\text {th }}$, 2014; accepted February $6^{\text {th }}, 2014$

\begin{abstract}
Copyright (c) 2014 Mbih Jerome Tosam. This is an open access article distributed under the Creative Commons Attribution License, which permits unrestricted use, distribution, and reproduction in any medium, provided the original work is properly cited. In accordance of the Creative Commons Attribution License all Copyrights (C) 2014 are reserved for SCIRP and the owner of the intellectual property Mbih Jerome Tosam. All Copyright (C) 2014 are guarded by law and by SCIRP as a guardian.
\end{abstract}

In this paper I argue that contrary to what some philosophers think, there exists a very close link between philosophy and medicine. From ancient Greece with Hippocrates to the modern era, philosophy has been at the basis of medicine. This is especially true of Western medicine which greatly depends on the philosophies of Bacon and Descartes. Although the two disciplines seem to pursue two disparate goalsphilosophy being the quest for truth while medicine is the quest for health, they are in complementary ways striving for the enhancement of human wellbeing. While medicine seeks to fight diseases of the body like bacteria and viruses, philosophy seeks to fight the diseases of the mind like half-truths, prejudices, woolly judgments and uncritical conceptions of the world, health and disease, which have direct impact on health, and health delivery. Using substantive examples, I show that the practice of medicine raises questions beyond the scope of medicine, questions to which only philosophy may provide answers because they fall within its scope. Daily, physicians are confronted with questions in such philosophical areas like metaphysics, epistemology, ethics, and logic. Moreover, I argue that one of the weaknesses of modern Western medicine is its over-dependence on the Cartesian ontology which considers human bodies as machines which need to be studied using scientific logic, and the physician as a technician whose job is to repair dysfunctioned bodies. This modern metaphysical outlook resulted in the neglect of the patient as a subjective being. This deficiency cannot be overcome without reviewing the Cartesian reductionist worldview which is at its foundation.

Keywords: Philosophy of Medicine; Modern Medicine; Metaphysics; Ethics; Logic; Epistemology; Subjectivity; Bacon; Descartes

\section{Introduction}

"Philosophy is the sister of medicine" Tertullian

The title of this paper may sound annoying to anyone who does not see or imagine any relation between philosophy and medicine (Caplan, 1992) because the two disciplines pursue (or seem to pursue) two distinct goals. Philosophy is the quest for truth while medicine is the quest for health. However, although the two disciplines seem to be unrelated, in reality, they are not. Philosophy and medicine have always influenced each other since the days of Hippocrates. Philosophy provides for the theoretical, methodological, and analytical tools for the analysis of concepts in medicine such as disease, health, and care. Medicine, on the other hand, provides philosophy with issues for critical reflection. The aim of this paper is to examine the task of philosophy in modern Western medicine.

It was traditionally thought that the business of philosophy in medicine was only in the ethical domain, but this is not the case. New developments in medicine provoke questions beyond the scope of medicine, questions to which only philosophy may be able to provide answers because they fall within the traditional scope of philosophy. Some of these questions include "What is disease?" "What is the nature of medical knowledge?"; "How reliable is such knowledge?"; "What is correct medical think- ing?”; "Is it ethical to engineer human beings with the use of biotechnology?" and "What does it mean to be human?" These are questions which physicians alone cannot provide complete answers, although they arise from their day-to-day practice. These questions fall within four main branches of philosophy, namely, metaphysics, epistemology, logic, and ethics.

This paper is divided into four sections. The first section is concerned with conceptual clarification. It examines the key concepts used in the paper. The second section discusses the philosophical foundations of modern medicine. Section three focuses on the role of philosophy in medicine. The aim is to show that the practice of medicine raises questions which are central to philosophy. Finally, section four argues for the centrality of subjectivity in medicine. Here I argue that the mechanistic ontology, inherited from Descartes, which prioritizes objectivity, ignores important values in the diagnosis and effective treatment of patients such as compassion, personal experience, history, social status, environment, and culture.

\section{Conceptual Clarification}

Four terms need elucidation here: philosophy, medicine, philosophy in medicine, and philosophy of medicine. By modern medicine I have in mind Western medicine as it developed from 
the $17^{\text {th }}$ century to the contemporary era. Although I trace the origin of modern medicine to ancient roots, my analysis is focused largely on its modern form.

Philosophers do not agree as to what it is they study. Although the definition philosophy is not a matter of consensus among philosophers, there is one common idea that may be deduced from the diverse definitions they offer. This is the idea that philosophy is the dispassionate search for truth. Philosophy attempts to understand reality and to find answers to foundational questions about life, knowledge, morality and human nature. The early Greeks defined it as the love of wisdom, that is, the insatiable desire to understand the world that surrounds us. Philosophy attempts to answer questions like "what is the meaning and purpose of life?" "What is happiness?" What is knowledge? "How do we know that we know?" By this, philosophy promotes intelligent inquiry, which helps to liberate us from the captivity of ignorance, prejudice, self-deception, parochialism, and half-truths.

The term medicine may be employed to denote any substance or drug used to treat disease or injury to the body or mind. Technically, medicine may be defined as "the art and science of diagnosis, treatment, and prevention of diseases, and the maintenance of good health” (Janicek \& Hitchcock, 2004). In this definition, medicine is considered not only as a science, but, also, as an art. As an art, medicine includes "sensory skills, and the systematic application of such skills and knowledge in language, speech, reasoning, and motion, in order to obtain desired results" (Janicek \& Hitchcock, 2004).

Medicine is an art because in the diagnosis and treatment of patients, physicians do not only base their decision on current knowledge, but, at times, and most often, on their imaginative and intuitive insight. The art of medicine therefore, involves "memory, listening to the patient, advising the patient, empathy, insight, equipoise, conceptualization, observation, and inference," which are "thought to be learned and/or improved by experience" (Montgomery, 2006). It is also for this reason that medicine is considered to be even more than a science "because it does not restrict itself to the formulation of laws and theories which hold under qualified conditions” (Montgomery, 2006). Hence, to be a good physician, knowledge alone is not sufficient; experience, intuition, imagination, and critical thinking are crucial.

According to Kathryn Montgomery, medicine "is neither a science nor a technical skill (although it puts both to use) but the ability to work out how general rules-scientific principles, clinical guidelines-apply to one particular patient.” She argues, further, that: "Despite its reliance on a well-stocked fund of scientific knowledge and its use of technology, it is still a practice: the care of sick people and the prevention of disease... Physicians draw on their diagnostic skills and clinical experience as well as scientific information and clinical research when they exercise clinical judgment. Bodies are regarded as rule-governed entities and diseases as invading forces... But neither is true. Patients with the same diagnosis can differ unpredictably, and maladies, even those firmly identified with bacteria or tumors or genetic mutations, are never quite things" (Montgomery, 2006).

The art of medicine involves practical reasoning, that is, critical thinking, intuition and sound judgment. It is from this perspective that Edmund D. Pellegrino, one of the most prominent contemporary philosophers of medicine, says "medicine is the most humanistic of the sciences, and the most scientific of the humanities" (Giordano, 2009). Apart from the fact that it is concerned with the human body, medicine is also concerned with the whole being of the patient. The problem with modern medicine is that it has ignored this humanistic dimension for the objective, material, and scientific aspects.

Philosophy in medicine is the philosophical analysis of issues in medicine, disease, health and care. It is the "use and application of philosophy to health, disease, and medical care. It is an activity whose aim is to study the general principles and ideas that lie behind our views, understanding, and decisions about health, disease, and care. Its objective is not a new or old finding...but the understanding of the concepts and principles used to interpret phenomena that surround us and that concern us. Philosophically understanding our views of the physical world and of the physical phenomena helps improve our biological understanding of health, disease and care" (Janicek and Hitchcock, 2004). For Pellegrino, philosophy in medicine is the use of "the formal tools of philosophical inquiry to examine the matter of medicine itself as an object of study" (Pellegrino, 1998). By this, he means "the application of the traditional tools of philosophy-critical reflection, dialectical reasoning, uncovering of value and purpose, or asking first-order questions - to some medically defined problem” (Pellegrino \& Thomasma, 1981).

The line separating philosophy of medicine from philosophy in medicine is not very neat and tidy, the two are intimately intertwined. Philosophy of medicine is the philosophical investigation into the nature of medicine. Schaffner and Engelhardt offer a definition that also includes philosophy in medicine. They argue that philosophy of medicine “... encompasses those issues in epistemology, axiology, logic, methodology and metaphysics" generated by or related to medicine. "Issues have frequently focused on the nature of the practice of medicine, on concepts of health and disease, and on understanding the kind of knowledge that physicians employ in diagnosing and treating patients” (Schaffner \& Engelhardt, 2000).

The idea is not that in philosophy of medicine philosophy assumes the role of medicine or that medicine appropriates the role of philosophy, but, simply, there exists an "overlapping division of labor" (Johannson \& Lynoe, 2008) between the two disciplines. The rapport "between the two disciplines is more than simply philosophy and medicine in that they share more than common problems and is more than philosophy in medicine in that philosophers use medicine not just to do philosophy but to understand the nature of medicine itself” (Marcum, 2008). It is from this light that James Marcum defines philosophy of medicine as "the metaphysical and ontological, the epistemological, and the axiological and ethical analyses of different models for medical knowledge and practice...” (Marcum, 2008).

\section{The Philosophical Foundations of Western Medicine}

In this section, I am concerned with the contribution of philosophy to the development of medicine. I am not concerned with the history of medicine per se, unless such history has a philosophical foundation. In his book, The Philosophical Foundations of Modern Medicine, Keekok Lee contends that: "No intellectual activity, whether it pertains to politics, economics, law or science is innocent of Philosophy, whatever its rhetorical proclamations may say. Hence to understand modern science 
and well as also modern medicine..., one must understand their philosophical foundations” (Lee, 2012). Although Keekok has modern medicine in mind, the history of science, and medicine as a whole, cannot be understood without a proper understanding of its philosophical foundations.

Beginning with the ancient Greeks, philosophy provided medicine with the methodological and analytical tools to examine issues related to disease and health. In this interactive process, medicine has also provided philosophy with material for philosophical contemplation. Although separate disciplines, each borrows the conceptual resources of the other for resolving problems.

The art of medicine is usually traced back to ancient Greece. Although it is right to trace the origin of medicine to ancient Greece, it is important to note that the Greeks were not the only people who may be credited for the invention of medicine. "Ancient Mesopotamia and Egypt had medical texts and traditions that long predated those of the Greeks" (Potter, 1996). There existed medical texts in India and China, which may be older than those of ancient Greece, although these had little or no influence on Western medicine until recently (Potter, 1996). In spite of fragmentary evidence to show there existed a medical tradition before Greek medicine, there is no evidence that it was as rational or as philosophical as Greek medicine. Early Greek medicine was characterised by "questioning, argumentative, and speculative discussions ... as found in the Hippocratic Corpus, the collection of some sixty tracts ascribed to Hippocrates" (Potter, 1996). It is for this reason that Hippocrates is considered as the father of medicine-medicine in its critical form.

In ancient Greece, medicine was an open art in which philosophers, root-cutters, physicians, priests, exorcists, bone-setters, surgeons, and even lay persons participated. The reflections of philosophers such as Empedocles and Plato had profound implications than those of some physicians. However, it is Hippocrates who gave medicine its lasting philosophical and scientific definition. Vivian Nutton notes, "in medical schools around the world students give assent to principles and words they believe go back to the Father of Medicine, and in the eyes of their prospective patients failure to live up to his prescriptions for competence and morality is the greatest of all medical sins” (Nutton, 2004). Hippocrates was an Asclepiad, a member of a family that claimed descent from Asclepius. It is at the time of Hippocrates that there began serious scientific contemplation about the nature and causes of disease.

Another important ancient physician whose philosophical and scientific contributions in medicine had an enduring influence on modern medicine was Galen. While Hippocrates is considered to be the father of Greek medicine, it was Galen who advanced and extended ancient medicine. He emphasized the role of proper observation and experimentation in medicine. But most importantly, Galen "considered the study of philosophy to be essential to a physician's training. Philosophy, enables the physician to discern between truth and illusion, or between reality and mere surface appearances, which is so important in diagnosis", and in the same perspective, he argued that it "was necessary for putting treatment on a sound ethical foundation" (http://www.greekmedicine.net/whos who/Galen.html).

A contribution which had a lasting impact on modern medicine was his mechanistic conception of the human person. For Galen, a person is in good health when all the organs and systems of the body are functioning properly. Disease was there- fore the result of anatomical dysfunction. Descartes and other modern philosophers of medicine were greatly influenced by this mechanistic conception of the human person. Galen carried out experiments on non-human animals to understand how the human body was structured, and how it functioned. For example, "by clamping the ureters of living apes and watching the kidneys swell, Galen concluded that the kidneys produce urine. By cutting or stimulating various spinal nerve roots, he figured out which organs and muscles they controlled”

(http://www.greekmedicine.net/whos_who/Galen.html). In the area of pharmacology, Galen developed different ways of measuring the effects of medicinal plants and substances and composed guide books on how to prepare medicines from them. In the modern era, medicine took a new and more critical approach.

Modern philosophy is at the basis of modern science. It is pointless to add that modern medicine is the product of modern science. It will be difficult to separate modern philosophy from modern science - the two have coevolved. The methodology established by Bacon and Descartes, the fathers of modern philosophy-cum-science, was the method modern medicine followed. The modern philosophers interpreted nature from a materialistic-mechanistic standpoint, a method that favoured reductionism which has been largely applied in modern medicine. Reductionism is the view that the whole (the human being) is no more than a combination or summation of its parts. According to this outlook, "once the parts were explained, the whole has been explained without residue” (Lee, 2012).

The quest to alleviate pain and suffering, to cure diseases considered incurable, enhance human capacities and to prolong life has always been at the heart of the modern Western medical scheme. Bacon and Descartes did not only stay short at theorizing, they proposed methods based on careful observation and experimentation, methods on which modern science has largely depended, that will help humans take control, and manipulate nature as they see fit. According to Bacon, the aim of science was "to provide the theoretical basis for generating technologies suitable for achieving this ideological goal” (Lee, 2012). He provided an extensive criticism of medical science of his day. Bacon argued that "medicine is a science which hath been... more professed than laboured, and yet more labored than advanced; the labour having been, in my judgment, rather in a circle than in progression” (Bacon, 1857). For him, if medicine was not based on real philosophy of nature, we may never efficiently achieve its goal: the treatment of disease and the prolongation of life. He argued that "the science of medicine, if it be destitute and forsaken by natural philosophy, it is not much better than an empirical practice” (Bacon, 1857). In a short text, Magnalia Naturae Praecipue quoad usus Humanos, which immediately follows his fiction, New Atlantis, Bacon invites us to find ways for "the prolongation of life: the restitution of youth in some degree: the retardation of age: the curing of diseases counted incurable: the mitigation of pain: more easy and less loathsome purgings: transformation of bodies into other bodies. The increasing of strength and activity. The increasing of ability to suffer torture or pain. The altering of complexions, and fatness and leanness" (Bacon, 1803).

From this, Bacon's dedication to the advancement of the science of medicine was without measure. Recent developments in medical science and human genetic engineering, in particular, may be considered as responses to that call. In Part Six of his Discourse on Method, Descartes makes a similar call. He invites us to investigate into and understand the secretes of 
nature so that "we might put them in the same way to all the uses for which they are appropriate and thereby make ourselves, as it were, the masters and possessors of nature." He adds that there is much still to be discovered in the domain of medicine if we sharpened our methodological tools: "I am sure there is no one, even among those who practise it, who does not admit that what is known of it is almost nothing compared to what remains to be known, and that we could free ourselves of an infinity of illnesses, both of the body and the mind, and even perhaps also of the decline of age, if we knew enough about their causes and about all the remedies with which nature has provided us" (Descartes, 1968). The optimism for the progress of medicine and its capacity to relieve humankind from many diseases was, therefore, a major part of the modern scientific projects of Bacon and Descartes. Descartes "resolved to devote the time left to me to live to no other occupation than that of trying to acquire some knowledge of Nature, which may be such as to enable us to deduce from it rules in medicine which are more assured than those we have had up to now" (Descartes, 1968). In his writings on medicine, Descartes made many pronouncements about the functioning of the human body, health, and how diseases are caused, which have survived our contemporary medical understanding of the human body. The influence of Bacon and Descartes to the development of modern medicine cannot be over-emphasised.

New developments in biotechnology as a whole and human genetic engineering in particular are the application and achievement of the ideological goals of science articulated by the fathers of modern philosophy some three hundred years ago. A major contribution of modern philosophy is that by emphasising on objectivity, that is, on the invaluable role of careful and critical observation and experimentation in understanding nature, this led to an epistemological shift in medicine from ancient and medieval approach which was fused with superstition and religion. Medicine was detached from the subjective and the spiritual, although this was not without a cost, as I show latter, which helped in giving medicine and the physician an empirical basis for viewing the human body.

\section{Philosophical Issues in Medicine}

As stated earlier, medical practice and research touch on questions in different areas of philosophy including metaphysics, epistemology, logic, ethics, and even politics. In this section, I focus on the first four areas of philosophy. Here I shall quote extensively from philosophers of medicine like James A. Marcum, Jerome Groopman, and Kathryn Montgomery. They, in my opinion, provide some of best analyses of the role of philosophy in medicine.

\section{Metaphysical Issues}

To begin with, metaphysics is a branch of philosophy which is concerned with the nature of reality. The term is derived from two Greek words: "meta” which means "after", "above” or "beyond", and "physics” which means "nature.” Hence, the term metaphysics literally means "after" or beyond nature. Metaphysics is concerned with things which are neither visible nor measurable-things which do not occupy space. The term has its origin from Aristotle's works, although he did not coin the term, exegetes (for example, Andronicus of Rhodes) of his works did. One branch of metaphysics, ontology, examines is- sues concerning the nature and existence of objects or events and their connected forces which are important in the understanding of concepts like disease and health. The two principal metaphysical issues for philosophers of medicine are disease and health, and their causes. The philosopher of medicine attempts to answer the questions: "What is/causes health?" or "What is/causes disease?” (Marcum, 2012). Another controversial issue for philosophers of medicine is the reductionism/ holism debate. At the heart of this debate are questions like: "Can a disease be adequately reduced to its basic components?" or "Is the patient more than simply the sum of his/her physical parts?"

A debate common to philosophers of medicine is the reductionism versus Holism debate. Reductionism is the reduction of complex objects or events to their constituent parts. In the field of Biology and Medicine, reductionism is in the way the human person, the patient, and disease are defined. Reductionists construe human beings as mere bodies built like machines, and disease is the result of a mechanical dysfunction (especially at the genetic and molecular level). This medical interpretation of a human being came from Descartes' metaphysical dualism, the view that the mind and the body are two separate substances. In his Treatise on Man, Descartes says "I suppose the body to be just a statue or a machine made of earth” (Descartes, 1998).

Holism, on the other hand, is the view that parts of a whole are in intimately related to one another, such that they cannot exist independently of the whole, or cannot be understood without reference to the whole. Holists construe the patient as an embodied being, not merely a combination of parts, or a thing, which can be measured or calculated in strict mathematical terms, without recourse to important human values such as emotion, feeling, and individual experience. The modern reductionist view of the human person has given some contemporary scientists the false impression that they can use genetic engineering to create 'perfect human beings' by simply eliminating unwanted genetic traits.

Modern medicine since Descartes has preoccupied itself solely with the material or physical self, giving very little or no attention to the psychosocial aspects of disease and health. It is in this regard that Hans Jonas argues writes: "a new reading of the biological record may recover the inner dimension-that which we know best-for the understanding of things organic and so reclaim for the psychophysical unity of life that place in the theoretical scheme which it had lost through the divorce of the material and mental since Descartes... In the mystery of the living body," Jonas adds, "both poles are in fact integrated" (Jonas, 1966).

Reductionism provides an incomplete view of human nature, disease and health. In his Zollikon Lectures, Martin Heidegger, in what has been described as his health warning to humanity (Wilberg, 2001), and in reaction to metaphysical reductionism in medicine, provides a phenomenological view of disease/ illness and health. For Heidegger, the question "what is illness?” cannot be answered "without distinguishing the measurable from the immeasurable” (Wilberg, 2001) aspects of the illness. Medical diagnosis and treatment depends solely on calculable and measurable dimensions - the physical body of the patient. Heidegger argues: "Blood pressure can be measured but not life pressures. Heart functioning can be measured but not loss of heart or heartbreak, heartlessness or disheartenment. The patient's experience of disease, in the form of pain or discomfort, emotional distress or depression, is not in itself anything mea- 
surable" (Wilberg, 2001).

Closely linked to the reductionism/holism debate in medicine is the metaphysical question: "What is disease?" Philosophers of medicine distinguish between four different concepts of disease. The first is the ontological view. According to proponents of this view, disease is an obvious entity whose existence is distinct from that of the diseased patient. For example, disease may be a condition caused by the infection of a microorganism, like a virus. Proponents of the physiological conception of disease, contend that defenders of the ontological view confound "the disease condition, which is an abstract notion, with a concrete entity such as a virus” (Marcum, 2008). Advocates of the physiological conception of disease maintain that "disease represents a deviation from normal physiological functioning" (Marcum, 2008). The third notion of disease is called "maladaptive mechanism", which focuses on the "biological history" of the individual organism. According to this view, to understand a disease, we need to go back into the biological history of the individual organism and not the group. The fourth notion of disease is the genetic notion, which maintains that disease is the "mutation in or absence of a gene" (Marcum, 2008). The central idea here is that because the genetic make-up of each patient is different, by understanding the genetic structure, physicians may be able to diagnose the disease and provide a precise treatment plan.

According to these four accounts of disease, health is simply considered as the absence of disease-a dysfunctioned condition "as opposed to pathology" (Marcum, 2008). In other words, if an organism is not sick, then it must be healthy. Most accounts of disease, and health, rely on the physical, quantifiable and measurable aspects of a person, they do not relate disease to the patient-the person. E. J. Cassel maintains that "disease theory has no logical relation to person-in disease theory it does not matter what person has the disease-and therefore, the common complaint that patients are overlooked in the treatment of their diseases is another way of stating that, in the intellectual basis of modern medicine, patients and their diseases are not logically related" (Cassell, 2004).

From the same angle, Heidegger asks: "How does one measure grief? Obviously we cannot measure it at all. Why not? Were we to apply a method of measurement to grief, this would go against the meaning of grief and we would rule out in advance the grief as grief" He adds: "One cannot measure tears; rather when one measures one measures at best a fluid and its drops but not tears... To what do tears belong? Are they something somatic or something psychic? Neither one nor the other", he argues. For Heidegger, "Being in pain is an experience of a human being not of their physical body. All diseases of the physical body and physical mind are the manifestation of an inner disease of the human being, experienced through the phenomenal body." According to Heidegger, therefore, it is by considering the human person from this holistic perspective that disease and health can be sufficiently understood for better diagnosis and treatment. For Wilberg, "the illiteracy of modern science" (Wilberg, 2001) consists in its reduction of the human person, health and disease, to only his/her physical body. It is not bodies or brains that fall sick but human beings. Heidegger's conception of disease and health is holistic; it includes the patient's bio-psychosocial and cultural dimensions-his/her Lebenswelt (life world), to borrow Husserl's terminology. What this implies is that the principle of objectivity, which led to the remarkable growth of modern science, is also responsible for its impoverishment. It does not regard human persons as embodied beings.

Another metaphysical issue in medicine is the realism/antirealism debate. Realism is the philosophical view that visible things and events are actual things and events, independently of the individual observing them. According to realists, even nonobservable things and events exist. For example, terms like bacteria and cell stand for real objects in the real world, which exist independently of the human minds trying to analyze and understand them. Moreover, for realist, scientific inquiry into real objects like bacteria and cells provide correct explanations of these objects. On the other hand, anti-realism is the philosophical view that visible objects and events are not actual objects and events as observed by an individual, but rather they are dependent upon the person observing them. It is the mind that builds or fashions them according its desires-influenced by "social and cultural values" (Marcum, 2008).

The realists/anti-realists debate occupies a key position in the philosophy of medicine and medical practice. For instance, a controversial question is "whether disease entities or conditions for the expression of a disease are real or not. Realists argue that such entities or conditions are real and exist independent of medical researchers investigating them, while anti-realists deny their reality and existence” (Marcum, 2008). An example of a medical condition where this debate is visible is the case of depression. According to realists, "the neurotransmitter serotonin is a real entity that exists in a real brain-apart from clinical investigations or investigators. A low level of that transmitter is a real condition for the disease's expression. For anti-realists, however, serotonin is a laboratory or clinical construct based on experimental or clinical conditions. Changes in that construct lead to changes in understanding the disease..." (Marcum, 2008). According to Clinical realists, to cure depression, a physician simply needs to restore serotonin levels of the patient. For clinical anti-realists, the diagnosis and treatment of depression cannot be achieved simply by calculating and balancing serotonin levels. At the heart of this debate is an ontological problem. The neurotransmitter is a mental creation com- pletely contingent on attempts to examine and interpret laboratory analysis into medical practice.

Causality is also a central philosophical concept in medicine. Aristotle was the first to provide a forceful account of causality. He maintained that there are four causes: material, what something is made of; formal, how something is made; efficient, forces responsible for making something; and final cause, the purpose or end for which something is made. In the $17^{\text {th }}$ century, Francis Bacon trimmed the four causes to two: the material and efficient cause. In his empiricism, David Hume subjected causation to a careful scrutiny. According to Hume, causality is nothing but the constant association of objects and events, without any ontological implication in terms of connecting the cause with the effect. For him, society has trained us to believe that something really exists between the cause and its effect. Hume's skepticism about the possibility of causation did not last long. With the advancement of science in the $19^{\text {th }}$, the material cause, not in the Aristotelian sense, endured as a means of explaining causality.

Causality is used in medicine to analyze both the cause of a disease and its therapeutic efficiency. In the medical domain, disease operates at the physical and chemical levels. For example, some disease conditions are said to be caused either by environmental factors or life-style of the patient. An example is 
the case of cigarette-smoking and lung cancer. "The relationship between cigarette smoking and lung cancer involves the strength of the association between smoking and lung cancer, as well as the consistency of that association for the biological mechanisms" (Marcum, 2008). The problem here is that this is only a probability since it is merely based on epidemiological evidence, and not a sufficient condition, because not all cigarette smokers contract lung cancer, even nonsmokers sometimes contract it too.

However, the modern interpretation of causality in medicine has been greatly influenced by the modern mechanistic worldview, especially the view of Descartes, which considers disease as a biological phenomenon, that is, the malfunctioning of the biological system considered from the cellular and molecular levels. It failed to recognize the fact that a disease is not an objective entity existing independently of the life world of the patient and the medical professional. It does not acknowledge the fact that one can be ill without actually suffering from a biological-bodily disease; there are psychosocial factors which may also account for a disease.

\section{Epistemological Issues in Medicine}

Epistemology is a branch of philosophy which is concerned with human knowledge-its nature, origin and scope, and the reliability of claims to knowledge. Epistemologists define it as the study of knowledge and justified belief. Epistemology attempts to answer questions such as: "what is the source of our knowledge?" "What is its structure, and what are its limits?" "How do we know that we know?" "What are the necessary and sufficient conditions for knowledge?” What makes justified beliefs justified? Is justification internal or external to our mind?" (http://plato.stanford.edu/entries/epistemology/ [accessed 07/11/2012])

Medical epistemology is the way physicians classify and prioritize the biological and psycho-social information of a patient. The main characteristic of medical epistemology "is found in its a priori assumptions about knowledge that determine which types of clinical data are relevant and which types are not." (Evans et al., 2012) Epistemological issues in medicine include but not limited to the following: Medical practice and uncertainty, the rationalism/empiricism debate, and the reliability of medical Knowledge.

A key epistemological problem which is common at all levels of general medical practice is medical uncertainty. Medical knowledge is always uncertain, imperfect, and incomplete. For this simple reason, medical knowledge is always liable to falsification. Renee Fox has identified three fundamental types of uncertainty affecting physicians, namely; incomplete mastery of existing knowledge, limitations in current medical knowledge, and the difficulty of "distinguishing between personal ignorance or ineptitude and the limitations of present medical knowledge" (Fox, 1959). She also identifies the gambles and subtle ways physicians use to evade uncertainty, through what she calls "counter phobic-grim joking" (Fox, 1959). This has to do with the different ways medical practitioners use to evade uncertainty. Sometimes this is done by devolving their responsibility of decision-making to the patient or simply sharing it with them.

Moreover, every piece of information or data from the diagnosis that the doctor uses in the treatment of a patient is theoretically opened to diverse diagnoses. "Every laboratory test has a false positive and a false negative rate associated with it” (http://www.sclespain.com/wpblog/ [accessed 12/10/2012]). Sometimes the physicians cannot tell with absolute certainty what is wrong with a patient. They may only make conditional or provisional pronouncements about a patient's condition. Uncertainty is very common in medical practice and “... although scientific and technological advances refine clinical problems and provide solutions, physicians still work in situations of inescapable uncertainty” (Montgomery, 2006). Constant awareness of the imperfection of the data at hand is essential for the safe and effective delivery of medical care. Christopher Dowrick contends that the physician is always in uncertainty about: "What problems are going to be presented to us by the next patient who comes through the door of the consulting room? We may not be sure whether his fatigue, headache or abdominal pain is the start of a serious and life-threatening condition or will prove to be caused by a straightforward and self-limiting viral infection. It is also often unclear what our patients' perceptions of their problems may be, what ideas they have about how their problems should be managed and what other hidden or complicating psychosocial agendas they may have" (Dowrick, 1999). For this reason, the physician does not limit him/herself to "the observation of certain phenomena and their relations in order to explain their structures and regularities. Instead, the practitioner puts science into practice and has to cope with the practical limitations of scientific knowledge. Apart from the scientific attitude, a physician must be able to evaluate scientific findings within the context of the individual medical situation at hand. The physician does not only know, but also knows what to do" (Dowrick, 1999).

There is always room for deliberation on the best available option to take with regard to the condition of a given patient. In such situations of uncertainty, the physician is divided as to what kind of medication to prescribe- - "antibiotics for otitis media or antidepressants for mild or moderate depression? Should we refer patients with prostatic symptoms to an urologist early or indeed at all?” (Dowrick, 1999). Moreover, all treatment plans do not produce the same results for patients with the same condition. As such, we are never very certain if a particular treatment will, with certainty, improve the health of a particular patient we have at hand.

To reduce uncertainty that arise in medical practice, most physicians today work in small groups of three or four with each member developing a special interest and specializing in a particular disease such as diabetes, asthma, HIV/AIDS, depression, etc. (Dowrick, 1999). With this, each partner opens a clinic which focuses on diseases in his/her area of interest where patients who consult with partner physicians are referred to the specialist partners for treatment and care. In other cases, some physicians may reduce uncertainty by specializing in those diseases that are more lucrative. This is, however, a dubious way of solving the problem of medical uncertainty (Dowrick, 1999), because it may result in the neglect of the diseases are less lucrative and which predominantly affect the poor.

The reliability of medical knowledge is another major epistemological issue in medicine. Diagnostic and therapeutic knowledge is always difficult to ascertain. The medical approach is to obtain the information through observation or physical symptoms and signs and laboratory examinations, to carefully reflect on that information, and to arrive at a conclusion concerning the disease condition of the patient. The problem, for philosophers of medicine, with this approach is that symp- 
toms and signs differ and how to measure the signs so as to categorize the diseases is difficult. However, "the discussion among philosophers of science over the strategy by which natural scientists investigate the natural world guides much of the debate. Thus, a clinician generates hypotheses about a patient's disease condition, which s/he then assesses by conducting further medical tests” (http://www.sclespain.com/wpblog/).

Sometimes it is difficult to obtain absolute knowledge about certain conditions. Knowledge of pain, for instance, is difficult to ascertain. S/he can only imaginatively put him/herself in the shoes of the patient; s/he cannot know what the patient feels. The physician can only understand what the patient tells her. For example, the doctor can take your pulse rate and measure your blood pressure, which may both be normal; s/he can observe you and do a complete physical examination and a series of laboratory tests and imaging studies, all of which may not enable him/her to identify the exact cause of your pain and cannot tell if you are truly in pain or not

(http://www.sclespain.com/wpblog/). One cannot therefore tell if a patient is in pain if we do not have compassion for the patient and/or take him/her at his/her word. In most cases, when a physician cannot explain the cause of a patient's pain, s/he tends to treat the patient as a liar or mentally deranged. This approach usually aggravates the patient's situation because it results in frustration since such rejection is coming from the person (physician) who is not only supposed to help relieve the pain, but also to show compassion for his/her suffering.

The rationalism/empiricism controversy is also visible in medicine. At the heart of this debate is the question: "What is the origin of our knowledge?" "Is knowledge deduced or inferred from first principles or premises?" "Or, is it the result of careful observation and experience?” (Marcum, 2012). According to rationalists like Descartes, knowledge is intuitive in nature and is solely the product of the human mind. For him, we cannot rely on sense experience because of its instability and unreliability, and its capacity to lead us astray. Empiricists, on the other hand, maintain that experience is the source of our knowledge.

In the domain of medicine, the rationalism/empiricism controversy has its origins in ancient Greek and Roman medicine. The rationalists argue that reason is enough for understanding the fundamental causes of a disease. Medical empiricists, on their part, maintain that only sense experience or observation, and not "theory", is sufficient basis for medical knowledge. They maintain that theory is an outcome of medical observation and experience, not its basis. The empiricist view which emphasizes experimentation dominates modern and contemporary Western medicine.

\section{Logic in Medical Decision-Making}

An important part of the job of physicians is decision-making, based on acquired knowledge and experience; and to do this efficiently, it is necessary for the physician to be equipped with the tools of clear thinking and/or correct reasoning. As K. Montgomery puts it, "no matter how solid the science or how precise the technology that physicians use, clinical medicine remains an interpretive practice. Medicine's success relies on the physicians' capacity for clinical judgment” (Montgomery, 2006). At a time when new knowledge keeps pouring and patients and the public are becoming more and more informed about their health or disease, the physician needs to be equip- ped with the challenges that come with new developments in medicine. Medical thinking requires some formal training in logic for better communication with patients, peers, and the health community and the public in general. Medical practice requires skill in reasoning, imagination, intuition, and critical thinking. The lack of this skill results in all forms of misjudgments and egregious errors in diagnosis and treatment. Jerome Groopman highlights this when he writes: “... What I and my colleagues rarely recognize, and what physicians still rarely discuss as medical students...throughout their professional lives, is how other emotions influence a doctor's perceptions and judgments, his actions and reactions. I long believed that the errors we make in medicine are largely technical onesprescribing the wrong dose of drug, transfusing a unit of blood matched for another person, mislabeling an x-ray for an arm as "right” instead of "left." But as a growing body of research shows, technical errors account for only a small fraction of incorrect diagnosis and treatments. Most errors are mistakes in thinking. And part of what causes these cognitive errors is our inner feelings, feelings we do not readily admit to and often don't even recognize” (Groopman, 2007).

In the same perspective, K. Montgomery argues that because of the uncertainty common in medical practice, the physician is faced with the daily challenge of comparing and selecting the right information for the treatment of individual patients with their distinct problems. She contends that: “...although scientific and technological advances refine clinical problems and provide solutions, physicians still work in situations of inescapable uncertainty. New diseases like human immunodeficiency virus (HIV) or severe acute respiratory syndrome (SARS) are the extreme examples, but everyday cases are uncertain, too. Useful information is available in overwhelming quantities, and physicians have the daily task of sorting through it and deciding how some part applies to an individual” (Groopman, 2007).

In order to do the "sorting" out of which information to use and which not to use for a particular patient, efficiently, the physician need to apply practical reasoning, phronesis, what Aristotle described as "the flexible, interpretive capacity that enables moral reasoners... to determine the best action to take when knowledge depends on circumstance. ... In medicine that interpretive capacity is clinical judgment...” (Groopman, 2007). In the process of decision-making in their daily interactions with patients, physicians employ, consciously or unconsciously, different forms of logical reasoning processes: different forms of propositions, inference, syllogism, dilemma, logical implication, probability theory, decision analysis, etc. The physician may make good use of the rules of these forms of reasoning, for the benefit of patients, if s/he has some formal training in logic. This logic differs from the logic of science, and it is the art of clinical judgment that makes medicine more of an art than a science.

Mastering and thoughtfully applying the principles of logic, both traditional and modern, is essential for the efficient practice of medicine. Logic permits the physician "to efficiently, consistently and without mistakes carry out all the reasoning and to prove the hypothesis in a formal way.” Logic permits us "to see the need to justify opinions through the means of argumentation. It gives certainty to the correctness of the formulated views. It informs how to recognize which of the justifications are indisputably certain and which are only to some extent likely" (Groopman, 2007). From this perspective, therefore, there is no doubt that logic is an indispensible tool in medical decision- 
taking, diagnosis, and treatment.

\section{Ethical Issues in Medicine}

As stated earlier, it was traditionally thought that the business of philosophy in medicine was essentially ethical; but, as I have argued so far, this is incorrect. Philosophy provides the methodological tools, ethical principles and theories for the scientists, health care providers, sociologist, anthropologists, lawyers, and theologians to discuss the issues that arise or may arise in medicine. This has been the task of bioethics, which is concerned with the ethical issues that arise from new developments in biomedicine. Developments and malpractices in biomedicine at the beginning of the second half of the $20^{\text {th }}$ century led to the birth of bioethics. Some of the prominent advancements at this time included the invention of life-support machines, used to extend the life of patients in persistent vegetative state; assisted reproductive technologies and genetic technologies, used to solve the problem of infertility. Some of the malpractices which resulted from medical advances include the inhumane program of the Nazi regime in Germany involving euthanasia, forced sterilization for eugenic reasons, and experimentation on human beings against and/or without their informed consent; the infamous Tuskegee case in the USA and many more. All of these were accompanied by an increasingly enlightened public which was no longer willing to give complete trust to health care professionals with regard to health matters. Most of the theories and principles used in resolving bioethical issues today have been derived from the theories of Plato, Aristotle, Locke, Kant, J.S. Mill, Rawls and many other philosophers. There are four cardinal principles of ethics commonly applied in modern medicine, namely, autonomy, beneficence, non-maleficence, and justice.

The principle of autonomy is usually considered as the first, though not the most important, principle of medical ethics. The term autonomy is derived from two Greek words: autos which mean "self" and normos which means "rule" or "law." Traditionally, the term autonomy was used to refer to the self-governance of independent states (Beauchamp and Childress, 2009), but today it has been used to include self-rule or self-determination. The principle of autonomy is based on the concept of respect for persons which holds that individual persons have rights to make their own choices and take decisions as they see fit, free from external constraints. Hence, the principle of autonomy means both the freedom of each individual to act and the obligation of others to respect that freedom. This principle has its origin in the Kantian concept of respect for persons. Kant entreats us to "treat humanity whether in your own person or in the person of another, always at the same time as an end and never simply as a means” (Kant, 1992). For Kant, human beings have "intrinsic worth i.e. dignity", which makes them valuable "above all price" (Kant, 1992).

In the domain of medicine and health care, the principle of autonomy is translated into the notion of informed consent. Informed consent is a legal condition where a rational being can be said to have given approval based on a full understanding of the facts and implications of any action, and not in any way under compulsion or his/her judgment impaired by misinformation or any illness. "A person of diminished autonomy... is in some respect controlled by others or incapable of deliberating or acting on the basis of his or her desires and plans" (Beauchamp \& Childress, 2009). Respect for autonomy, therefore, requires that we respect the point of view of a patient, his or her culture, beliefs, and customs. Hence, the principle of autonomy is based on the moral obligation of respect for other human beings as moral equals. Like the other cardinal principles of ethics, autonomy is essential in health care because health care professionals deal with human bodies - their whole being, and as Gerald Dworkin observes, “one's body is irreplaceable and inescapable. If my architect doesn't listen to me and this result in a house I don't like, I can always move. I cannot move from my body... because my body is me, failure to respect my wishes concerning my body is a particularly insulting denial of my autonomy” (Dworkin, 1988). My body is part of what I am-a human being, not a commodity which can be bought and sold, or an artefact which can be modified or tinkered in different forms, without causing any grave harm on my being as a whole.

The principles of beneficence and non-maleficence are other central principles of ethics employed in the resolution of medical quandaries. Although these are two separate ethical principles, beneficence and non-maleficence are best discussed together because one is the converse of the other- "they are like two sides of the same coin" (Tangwa, 2011). Beneficence is the positive obligation to act for the good/benefit of others/patients, and non-maleficence is the negative obligation to avoid harm to others. The term beneficence refers to acts of "mercy, kindness and charity and is suggestive of altruism, love, humanity, and promoting the good of others” (Beauchamp, 2008). Beneficent acts exclude supererogatory acts, that is, giving beyond what is required. For example, self-sacrifice, involving risky and costly acts to benefit others like donating both of our kidneys for transplantation. Non-maleficence on the other hand is said to be the most basic of the four principles of ethics. In medical ethics, non-maleficence is linked to the saying primum non nocere: "Above all [or first] do no harm.” The Hippocratic Corpus expresses the obligation of a physician to promote the good of the patient and avoid harm: "I will use treatment to help the sick according to my ability and judgement, but I will never use it to injure or wrong them." However, we may not be able to do good at all times, but we must avoid harm to others at all cost. Hence, according to the principle of non-maleficence, "even if you would not do good, at least do no harm” (Tangwa, 2011).

The principle of Justice is another cardinal principle applied in issues in modern medicine. The term justice is derived from the word 'just' which means righteous, fair, well-founded, proper, correct, exact, not more than barely, not less than. (Onions, 1998). The question of justice has preoccupied philosophers since the days of Plato. If a society must attain some degree of order, harmony and fairness, it must seek to reach for some degree of justice within its institutional framework. John Rawls argues that: "justice is the first virtue of social institutions, as truth is of systems of thought. A theory however elegant and economical must be rejected or revised if it is untrue; likewise laws and institutions no matter how efficient and well-arranged must be reformed or abolished if they are unjust” (Rawls, 1999). In health care, the principle of justice requires the fair and equitable distribution of medical goods and services.

With the development of medical science, the indispensable place of justice has become more and more evident. In the 1960s justice in the medical setting, on the part of the physician, was conceived as acting fairly to the patient. But as the decades have passed, it has been realized that no nation, no matter how wealthy it is, can make available all that medicine has to offer. 


\section{Modern Medicine and the Patient: A Call for Medical Subjectivity}

The achievements and benefits of modern Western medicine have become so evident and so natural that it may be difficult to imagine other rational ways of perceiving the human body, and treating patients (Ravez \& Tilman-Cabiaux, 2011). Western medicine is ordered around two main principles: In its ambition for scientificity it tries to fulfill the principle of objectivity and universality (Leyens, 2011). Inherited from Bacon and Descartes, science describes and explains the structure of the world independently of particular or subjective phenomena. Although science deals with objective and cool facts, the field of medicine, as distinct from technology and other sciences, deals with individual human beings (Clifton-Soderstrom, 2003). The Cartesian ontology, which considers human bodies as machines and medical practitioners as technicians whose job is to repair those machines, has resulted in the dehumanization of modern medicine. This problem cannot be overcome without dismantling the modern Cartesian philosophical reductionist worldview which is at its root.

However, from its objective of diagnosing diseases and treating individual patients, medical practice is also closely linked with subjectivity and personal experience, the most neglected aspect in medicine today. This is because the doctor or health care provider does not only treat the 'body' subjected to the causal laws of nature, s/he treats a particular being-a subject, who has a personal history, a will, desires and anxieties which are all associated with his/her illness. There is a causal relation between the human being, his or her environment and health. The World Health Organization's definition of health takes into account this holistic and encompassing dimension of health: "Health is a state of complete physical, mental and social well-being and not merely the absence of disease or infirmity" (WHO, 1948).

By subjectivism I mean individual experience of the patient about his/her disease and health. In medicine, this entails taking the patient's point of view (emotion, culture, story, environment, economic situation, and the meaning s/he gives to his/her illness), seriously. This is the humanistic approach to medicine (Riordan, 1976). Although subjectivity and medicine seem to be strange bed fellows today, it was not traditionally the case. It was an important part of ancient Greek medicine. In diagnosing a disease, the physician paid attention to the suffering of the patient, his/her feelings, and sensation, as well as clinical symptoms. Ancient Greek medicine was holistic. It took into account the physical, natural, environmental, and supernatural, factors of disease and treatment. One major challenge of modern medicine is to reconcile these two seemingly distinct, but intimately related aspects of the human person. To take these factors into account, the physician must be able to develop a compassionate attitude towards the patient; s/he "must draw closer to the patient, putting the interests of other above those of self, even at some sacrifice to oneself (Shapiro, 2008). Though it may be argued that psychiatry has taken up this subjective role, psychiatry has been mainly preoccupied with the treatment of patients with mental health problems; it has not been concerned with health issues of the broader medical public and has not been given the place it deserves in medicine today. In fact, "psychiatrists can be catalysts for change in the rapidly changing health care environment due in part to their unique training in the full spectrum of medicine, their expertise in behavior change, and their knowledge of group dynamics and team participation” (Raney, 2013). Extending and accommodating the role of psychiatry in all areas of medical care may greatly improve health care delivery.

The patient must be seen as an embodied being and not merely a defective machine waiting for the technician to use his/her technical know-how to repair its dysfunctional parts. It is its consideration of the body as a machine that modern medicine has been considered to be too impersonal and uncompassionate towards the patient. Paying attention to the particularity of each patient makes medicine more humane. This can only be by incorporating the psychosocial and cultural dimensions of illness. For practitioners of humane medicine, "the body and the mind are complimentary aspects of the patient and both must be considered when making a diagnosis or choosing a therapy. For the patient's illness may be more than simply organic but may also include the biopsychological and informational” (Marcum, 2008).

Modern medicine has concentrated on the disease to the neglect of the patient, as if the disease and the patient were two separate and distinct entities. It has neglected the view that the patient may actually be treated without taking any form of medication. Understanding the medical story, beliefs, social background, and culture of the patient may permit the physician to easily diagnose and provide better treatment. Medical stories are unlike everyday stories in one important way: "They always have at least two characters-a person and that person's body. (There are no persons without bodies, but there can be bodies without persons, as we have discovered in this age of long-term artificial support of the almost dead)" (Casell, 2004). To support this claim, Eric J. Cassell recounts the story of an old man with pneumonia which gravity is intimately linked to his story and social condition: "The story of the old man includes the social facts of his solitude, the personal matter of his bereavement, his living conditions, his bad knee, his failure to maintain proper nutrition, the invasion of the pneumococcus, its progress in his lungs, his worsening infection, collapse, being discovered, being brought to the hospital, antibiotics, respirator support, and so on. Thus, the search for the cause of an illness is not helped by classical disease theory, which does not account for all the facts" (Casell, 2004).

The implication of this story is that a disease is not only reduced to its physical and organic component. The relation between the doctor and physician is a "mysterious" (Cassell, 2004) one. If in seeing the patient, the physician takes care of his/her emotion, story, and personal experience, this may lead to better diagnosis and treatment. Treating sick people morally, listening to them, avoiding being judgmental, and not exploiting them, helps in diagnoses and better health delivery (Scott et al., 2009). But the objective and impersonal approach to medicine has made "the voice of the patient to be lost amidst the voice of health care providers and technology" (Clifton-Soderstrom, 2003), and encouraging a form of medical tyranny against the patient. A change of this mentality may only be possible when we begin to treat others with compassion, seeing ourselves as others and others as ourselves. It is in this way that "the suffering of others becomes our own suffering” (Shapiro, 2008). This shows the limitation scientific objectivity, "but offers an important psychological position from which empathy for others will naturally and meaningfully emerge” (Shapiro, 2008).

\section{Conclusion}

Although philosophy and medicine seem to be separate dis- 
ciplines, they are closely related. There is an "overlapping division of labour" between the two disciplines. Philosophy provides the analytical and methodological tools for examining issues in medicine while medicine provides issues for philosophical reflection. In the day-to-day practice of medicine-diagnosing and treating patients, philosophical issues in such areas like metaphysics, epistemology, logic, and ethics, arise. Also, there is a sense in which both philosophy and medicine pursue the same goals in that both aim at the search for human wellbeing. Philosophy is aimed at fighting the diseases of the mind-half truths, prejudices, uncritical conceptions of health and disease, and woolly judgments, which may have a direct impact on health and health care delivery. Medicine, on the other hand, is aimed at fighting somatic diseases-bacteria, viruses, tumors, genetic mutations and all the diseases that affect the human body. The truth and understanding at which philosophy pursues is to achieve happiness - to heal the soul. Also, the health at which medicine pursues is also to achieve happiness - the health of the body. Both disciplines therefore have therapeutic ends.

\section{REFERENCES}

Bacon, F. (1803). The works of Francis bacon, baron of Verulam, viscount St Alban, and lord high chancellor of England. London: $\mathrm{H}$. Bryer.

Bacon, F. (1874). The advancement of learning. In J. Spedding, R. L. Ellis, \& D. D. Heath (Eds.), The philosophical works of Francis Bacon (Vol. III). London: Longman.

Beauchamp, T. L., \& Childress, J. F. (2009). Principles of biomedical ethics (6th ed.). New York: Oxford University Press.

Beauchamp, T. L. (2008). The principle of beneficence in applied ethics. http://plato.standford.edu/entries/principle-beneficence

Caplan, A. (1992). Does the philosophy of medicine exist? Theoretical Medicine, 13, 67-77. http://dx.doi.org/10.1007/BF00489220

Cassell, E. J. (2004). The nature of suffering and the goals of medicine. New York: Oxford University Press. http://dx.doi.org/10.1093/acprof:oso/9780195156164.001.0001

Clifton-Soderstrom, M. (2003). Levinas and the patient as other: The ethical foundation of medicine. Journal of Medicine and Philosophy, 28, 4. http://dx.doi.org/10.1076/jmep.28.4.447.15969

Descartes, R. (1968). Discourse on method and meditations. Translated by F. E. Sutcliffe. New York: Penguin Books.

Descartes, R. (1998) Treatise on man. In S. Gaukroger (Ed.), The world and other writings. Cambridge: Cambridge University Press. http://dx.doi.org/10.1017/CBO9780511605727.008

Dowrick, C. (1999). Uncertainty and responsibility. In C. Dowrick, \& L. Frith (Eds.), General practice and ethics: Uncertainty and responsibility. London: Routledge.

Dworkin, G. (1988). The theory and practice of autonomy. Cambridge: Cambridge University Press.

http://dx.doi.org/10.1017/CBO9780511625206

Evans, L., et al. (2012). Epistemology and uncertainty: A follow-up study with third year medical students. Family Medicine, 44, 1.

Giordano, J. (2009). Quo vadis: Philosophy, ethics, and humanities in medicine: Preserving the humanistic character of medicine in a biotechnological future. Philosophy, Ethics, and Humanities in Medicine, 2, 4-12. http://dx.doi.org/10.1186/1747-5341-4-12

Groopman, J. (2007). How doctors think. New York: Houghton Mifflin Company.

Janicek, M., \& Hitchcock, D. L. (2004). Evidence-based practice: Logic and critical thinking in medicine. Chicago, IL: American Medical Association Press.

Johannson, I., \& Lynoe, N. (2008). Philosophy and medicine: A twenty first century introduction. Franfurt: OntosVerlag. http://dx.doi.org/10.1515/9783110321364

Jonas, H. (1966) The phenomenon of life: Towards a philosophical bi- ology. New York: Delta Book.

Kant, I. (1992). Grounding for the metaphysics of morals. In L. M. Michael (Ed.), Classics of moral and political theory. Indianapolis: Hackett Publishing Company.

Lee, K. (2012). The philosophical foundations of modern medicine. Hampshire: Palgrave Macmillan.

Leyens, S. (2011). Subjectivité et soin palliatives: De l’idéal a la pratique. In L. Ravez, \& C. Tilman-Cabiaux (Eds.), La Médicine Autrement! Pour une Ethique de la Subjectivité Médical. Namur: Presses Universitaires de Namur.

Marcum, J. A. (2008). An introductory philosophy of medicine: Humanizing modern medicine. Springer Science.

Marcum, J. A. (2012). Philosophy of medicine. http://www.iep.utm.edu/medicine/

Montgomery, K. (2006). How doctors think: Clinical judgment and the practice of medicine. New York: Oxford University Press.

Nutton, V. (2004). Ancient medicine. London: Routledge.

Onions, C. T. (1998). Oxford dictionary of english etymology. Oxford: Oxford University Press.

Pellegrino, E. D., \& Thomasma, D. C. (1981). A philosophical basis of medical practice. New York: Oxford University Press.

Pellegrino, E. D. (1998). What the philosophy of medicine is. Theoretical Medicine and Bioethics, 19, 315-336. http://dx.doi.org/10.1023/A:1009926629039

Potter, R. (1996). Cambridge illustrated history of medicine. Cambridge: Cambridge University Press.

Raney, L. (2013). Integrated care: Evolving role of psychiatry in an era of health care reform. Psychiatric Services, 64, 11. http://dx.doi.org/10.1176/appi.ps.201300311

Ravez, L., \& Tilman-Cabiaux, C. (2011). La Medicine autrement! Pour une éthique de la Subjectivité Médical. Namur: Presse Universitaires de Namur.

Rawls, J. (1999). A theory of justice. Cambridge: Harvard University Press.

Riordan, H. (1976). A humanistic approach to medical practice. Dialogue: A Kansas Journal of Health Concerns, 3, 4.

Schaffner, K. F., \& Engelhardt, T. (2000). The philosophy of medicine. In E. Craig (Ed.), Concise routledge encyclopedia of philosophy. London: Routledge.

Scott, J. G., et al. (2009). Healing relationship and the existential philosophy of martin Buber Philosophy, Ethics, and Humanities in Medicine. http://www.peh.med.com/content/4/1/11

Shapiro, J. (2008). Walking a mile in their patients' shoes: Empathy and othering in medical students' education." Philosophy, Ethics, and Humanities in Medicine, 3, 10. http://www.peh.com/content/3/1/10 http://dx.doi.org/10.1186/1747-5341-3-10

Tangwa, G. B. (2011). Ethics in African education. In A. B. Nsamenang, \& T. M. S. Tchombe (Eds.), Handbook of African educational theories and practices: A generative teacher education curriculum. Bamenda: Press Universitaire D'Afrique.

WHO (1948). Preamble to the constitution of the world health organization as adopted by the international health conference. New York, 19-22 June, 1946; signed on 22 July 1946 by the representatives of 61 States (Official Records of the World Health Organization, no. 2, p. 100) and entered into force on 7 April 1948.

Wilberg, P. (2001). Human ontology or human genomics? Heidegger's health warning to humanity.

www.meaningofdepression.com/Human\%20Ontology.ppt 